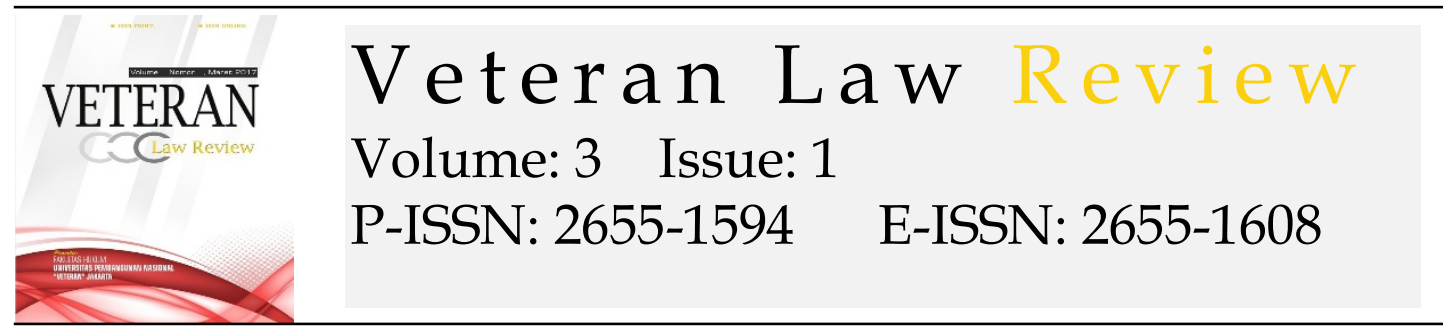

\title{
Suspicious Financial Transactions From Narcotic Trading Result As Origin Criminal Measures In Money Laundering
}

\author{
Yuni Priskila Ginting
}

Doctor Of Law Pelita Harapan University, E-mail: priskilamelody.ginting@gmail.com

\begin{tabular}{|c|c|}
\hline ARTICLE INFO & ABSTRACT \\
\hline $\begin{array}{l}\text { Keywords: } \\
\text { Financial Transactions; } \\
\text { Narcotic; Money Laundering } \\
\text { How to cite: } \\
\text { Ginting P.G. (2020). } \\
\text { Suspicious Finansial } \\
\text { Transactions From } \\
\text { Narcotic Trading Result } \\
\text { As Origin Criminal } \\
\text { Measures In Money } \\
\text { Laundering. } \\
\text { Veteran Law Review. 3(1). } \\
\text { hlm. 1-11 }\end{array}$ & $\begin{array}{l}\text { This study examines problem of Illegal drug use supports the legal } \\
\text { business activities with the modus of transfering to and hiding the } \\
\text { property obtained through a criminal in a legal institution and do the } \\
\text { money laundering through a finance institution that the property is } \\
\text { regarded being legal. In fact money laundering not always gradually, } \\
\text { but rather be combined the stages then do the step over and over that } \\
\text { involves manyparties and institutes that provides goods and services. } \\
\text { It has to be proven that the prepetrator knows or should suspect the } \\
\text { predicate crimes and whether or not double criminality principle } \\
\text { fulfilled.The author discusses the authority of the National Narcotics } \\
\text { Agency related to the money laundering carried out by criminal } \\
\text { suspects narcotics, And cooperation conducted by the National } \\
\text { Narcotics Agency with the Center for Financial Transaction Reports } \\
\text { Analysis related to the prevention and eradication of money } \\
\text { laundering. Modus of money laundering can be classified into three } \\
\text { types of typology such as placement, layering, and integration. } \\
\text { Elements of criminal acts are assets and the subject was person, bank, } \\
\text { and law enforcement. }\end{array}$ \\
\hline
\end{tabular}

\section{Introduction}

Narcotics cases in Indonesia are on a level that very worrying. As we know also the use of narcotics is also affected indonesia young generation and damage the state of the country's economy because the transactions are known to be large and come from abroad and involve the authorities who take part in the results that can be estimated to reach millions or hundreds of millions of rupiah. ${ }^{1}$ Globalization made society development in the fields of life is not only give positive impact on improving the quality of life, but on the contrary also has a negative impact along with its development in various forms of crime. Including illegal narcotics trafficking is growing because of lack of effective checks between the nations thus grow easily narcotics distribution.

The practice of money laundering was initially carried out only on money obtained from trafficking in narcotics trafficking and narcotics-type drugs or

${ }^{1}$ Gatot Supramono, (2007), Hukum Narkoba Indonesia, Jakarta:Penerbit Djambatan, page. 2 
known as illegal drug trafficking, and growing against money earned from sources of narcotics trafficking crimes. ${ }^{2}$ Starting from the legal umbrella of Law Number 08 Year 2010 is the attention to the practice of money laundering in Indonesia seems to increase, although previously there was a polemic about whether or not to immediately criminalize. The motivation to launder the proceeds of crime is at least because here are some concerns the perpetrators will deal with the tax officials, or will be prosecuted by law enforcement or even the proceeds of the crime will be confiscated.

Wealth derived from narcotics trafficking generally do not directly used by perpetrators of crime, because if used directly it will be easily tracked by law enforcement regarding the source of the acquisition of these assets. ${ }^{3}$ Narcotics trafficking crime is closely related to the process of money laundering, because narcotics trafficking is part of organized crime and money laundering is a way to manipulate the outcome. Ease and quickness in perform financial transactions are then used by drug traffickers to hide or disguise their assets obtained from the proceeds of crime by inserting illegal funds originating from narcotics trafficking into legal business.

Development of narcotics abuse and illicit trafficking has reached an alarming situation, so that it becomes an urgent state problem. Mode of money laundering growing and not only narcotics trafficking but also various crimes including organized crime. ${ }^{4}$ Money laundering is a follow up economy that provides an overview of the direct relationship that means the continuation of the crime and economic growth. ${ }^{5}$ Wealth obtained from narcotics trade transaction crimes is usually by the perpetrators of crime, both individuals and corporations are not directly used because of fear and indicated by the as an activity money laundering. ${ }^{6}$

Narcotics traffickers always try to conceal the origin of the assets resulting from narcotics trafficking in various ways which include trying to put it in the financial system (banking system), the means taken in the form of hiding or disguising the origin of these assets with the intention to avoid tracking efforts by law enforcement officials which are usually termed money laundering or popularly known as money laundering. Development of narcotics trafficking is needed to coordinate and cooperate with law enforcement agencies and officials involved in the laws and regulations governing narcotics crime. Money laundering crime as a crime classified as very serious is categorized as white collar crime because of the impact caused by the complexity of the criminal methods and the perpetrators who commit it.Money laundering have

2 Article 1 paragraphs (1) Law of the Republic of Indonesia Number 8 of 2010 concerning Prevention and Eradication of Money Laundering Crimes (Lembaran Negara Republik Indonesia Tahun 2010 Nomor 122, Tambahan Lembaran Negara Nomor 5164)

3 Pathorang Halim, (2013), Penegakan Hukum terhadap Pencucian Uang di Era Globalisasi, Yogyakarta:Total Media, page. 9

${ }^{4}$ Fredy BL. Tobing, Aktifitas Drugs Trafficking Sebagai Isu Keamanan Yang Mengancam Stabilitas Negara, Jurnal Global Politik Internasional, Vol. 5, No. 1, November 2002, page. 83

5 Teguh Sulistia dan Aria Zurnetti, (2011), Hukum Pidana: Horizon Baru Pasca Reformasi, Jakarta:Rajawali Pers, page.105

${ }^{6}$ Bismar Nasution, (2008), Rejim Anti Money Laudering di Indonesia, Bandung:Books Terrace \& Libarary, page.1 
the characters referred to as low visibility, complexity, diffusion of responsibility, ambiguous criminal law and weak detectionand prosecution. ${ }^{7}$

Narcotics crime as a core crime in the Law of the Republic of Indonesia Number 8 of 2010 concerning Prevention and Eradication of Money Laundering Crimes is expected to be able to overcome various modes that utilize banking institutions as a place for illegal activities that support illegal narcotics circulation activities, through the regime approach anti money laundering is not only physically the perpetrator can be detected but also the assets of the proceeds of original crime so that the perpetrators of money laundering carried out by actors who use the banking as a place for narcotics illicit trafficking transactions can be held accountable because in the principle of money laundering the main thing to be pursued is money or assets obtained from the proceeds of crime for several reasons. First, if chasing the culprit is harder and risky. Secondly, when compared to chasing perpetrators it will be easier to pursue the results of crime. Third, the proceeds of crime are the blood that supports the crime itself (live bloods of the crime). If the proceeds of crime are pursued and confiscated for the state, it will automatically reduce money laundering crimes. ${ }^{8}$

Illegal narcotics and drug abuse crime is an opportunity to support the business activities with the transfer mode, hiding assets resulting from narcotics crime to legal institutions and money laundering through financial institutions so that assets are considered legal assets. Furthermore, through this mode, the perpetrators continuously fund llegal business activities. This requires that the most dominant instrument in the Money Laundering criminal act usually uses banking, one of the reasons for the use of banking as the dominant instrument used by actors is based on offering the most financial instruments when compared to other financial institutions. Utilization of banks in money laundering can be either: ${ }^{9}$

a. Save money resulting from criminal acts under false names.

b. Save money in the bank in form of deposits/savings/ accounts/demand deposits.

c. Change bills of crime proceeds with other bills that are larger or smaller.

d. Use the transfer facilities.

e. Conduct a fictionalized export-Import transaction using L/C by falsifying documents in collaboration with relevant persons.

f. Establishment / utilization of illegal banks.

\section{Method}

Normatif's method of study is based on a number of reasons, according to the disciplines of the authors, in this case, that is law. Legal problems with much of one's life in society, especially the development of narcotics criminal

7 Harkristuti Harkrisnowo, (2004), makalah "Kriminalisasi Pencucian Uang (Money Laundering)",Jakarta, page. 2

8 Bismar Nasution, Op.cit, page. 2

9 Edi Setiadi, (2004), Hukum Pidana Ekonomi, Fakultas Hukum Universitas Islam Bandung:Bandung, page.71 
offenses which can lead to new criminal acts in the form of money laundering and the absence of harmonization of law enforcement in the sector or region that becomes the authority and duties of each agency or the institution. Besides the existence of the sectoral ego, it actually weakens the enforcement of the law itself, so that it becomes a challenge for the authors to conduct research using normative legal research methods. Normative legal science which is full of values and distinguished from social science, in which law does not use truth empirically. Legal research is a process of finding legal rules, legal principles, and legal doctrines to address the legal issues encountered. ${ }^{10}$

Legal research methods, qualitative analysis base the corroboration on theories, doctrines and opinions of lawmakers and on the formulation of legislation. While the underlying justification of qualitative analysis in social science is fact or experiment. ${ }^{11}$ In this study the author will deal with both points and will also deal with rules relating to the subject. The discussion includes the author's analysis of developments that deal with the subject and the writer's opinion of the application of rules that relate to the subject. The approach in normative legal research is very important to determine the scientific value of research. ${ }^{12}$

This study uses theory, legal material and non-legal material obtained and will be classified, described, matched, and analyzed for problem solving. Data analysis is the most important part in a scientific work because in this section every data obtained by the author will be explained which can answer research. In the study two types of reasoning that are used include deductive and inductive research methods. ${ }^{13}$

\section{Main Heading of the Analysis or Results}

\subsection{The relationship of narcotic criminal offence as an original criminal act on Money laundering}

Money laundering works originated from criminal acts. Criminal deeds are acts that are prohibited by law and are threatened with penalties for violating the prohibition. According to its form or nature, the criminal acts are deeds against the law and also harm the community in the sense of contradicting or hindering the implementation of the order in the life of the community which is considered good and fair. From the description it can be concluded that a deed will be a criminal act, if the act is against the law, harms the public, prohibited by criminal rules, the perpetrators are threatened with criminal. In criminal acts the implementation will be shown to an object. In the pattern of money laundering the proceeds of the offense are made again with an act which results in the proceeds of the offense. Therefore, all cases of money

\footnotetext{
10 Peter Mahmud Marzuki, (2011), Penelitian Hukum, Jakarta: Kencana, Cet. 7,, page. 35

11 Meray Hendrik Mezak, (2006), Jenis Metode, dan Pendekatan dalam Penelitian Hukum, Legal Review:Fakultas Hukum Universitas Pelita Hatapan, page.94

12 Johny Ibrahim, (2007), Teori dan Metodologi Penelitioan Hukum Normatif, Surabaya:Bayumedia Publising, page.299

${ }^{13}$ Mike McConville dan Wing Hong Chui (eds), Research Methods for Law, page.21
} 
laundering, especially with the original criminal acts of narcotics, the National Narcotics Agency will investigate the case.

Several laws and regulations in Indonesia since 1955 have indeed accepted corporations as the subject of criminal offenses, one of which is Law No. 8 of 2010 concerning Prevention and Eradication of Money Laundering Crime which is still valid until today. This shows the fact that the existing golden opportunity is not utilized by law enforcers, so coloring the criminal law, especially in its application is helpless facing corporate crime which is getting worse day. Related to the crime of money laundering conducted by the corporation, its punishment is regulated in Law Number 8 Year 2010 concerning Prevention and Eradication of Money Laundering Article 6 paragraphs (1) and (2), Article 7 paragraph (1) and (2), Article 8 and Article 9 paragraph (1) and (2).

In the crime of money laundering is always related and can not be eliminated the original criminal act and the existence of an act committed against the results of the crime and there is a wealth of the crime proceeds. Original criminal offense is a violation or crime that previously could be used to increase the sentence imposed for later crimes, the original criminal offense is determined by law and is not uniform in each country. Narcotics crime acts belong to the category of "economic gain" or generates economic profit, which are usually done by corporations or criminal organizations or syndicates. It can be determined to be in a criminal offence with money laundering to obscure the proceeds of crime. The need for coordination between law enforcement agencies in dealing with criminal agreements in narcotic crimes with money laundering because of the outcome of narcotics crimes really promise large profits.

In general, the active perpetrator is a criminal or predicate crime (predicate crime). However, it is evolved that those classified as active perpetrators here are not only the main perpetrators or everyone whocommitted the predicate crime, but also those who assist or participate in committing the crime of money laundering by disguising or hiding the proceeds of the crime so that the origin of the fund is unknown and can turn into halal money (clean money), and this is as regulated in Article 10 of the Law No. 8 of 2010. The provisions of this Article differ from those contained in the Criminal Code, and where in the Criminal Code the maximum penalty on the perpetrator of trial and assistance is the maximum principal penalty minus one third. Such provisions do not apply to trials and assistance in committing the crime of money laundering because they are subject to the same penalties as the main perpetrators in Articles 3, 4 and 5 of Law No. 8 of 2010.

Money laundering process can be grouped into three stages of activity that is placement, layering and integration. In practice these three activities can occur separately or simultaneously, but are generally overlapped:

1. Placement is the effort to place cash that comes from a criminalact into the financial system or efforts to place checks (checks, bank notes, certificate, deposits and others) back into the financial system, especially banking system. The forms of placement activities include: 
a. Placing funds in the bank. Sometimes this activity is followed by the submission of credit/financing.

b. Depositing money to financial service providers as credit payments to obscure audit trail.

c. Smuggling cash from one country to another.

d. Finance a business that is legitimate or related to a legitimatebusiness in the form of credit/financing, thereby turning cash into credit/financing.

e. Purchase valuable items of high value for personal use, buy valuable gifts as rewards to others whose payments are made through a financial service provider.

Placement of narcotics crime as predicate crime can be qualified from the actions of the perpetrator by hiding or disguising the origin of assets obtained from drug crime so that it appears as if the assets resulting from narcotics crime are the result of legal activities.

2. Layering is an effort to transfer assets derived from criminal acts (dirty money) which has been successfully placed on the financial service provider (especially banks) as a result of placement efforts to other Financial Service Providers. With layering, it will be difficult for law enforcers to be able to know the origins of the property. At this stage the offender makes transactions obtained from illegal funds into highly complex and multi-layered and sequential transactions protected by various forms of anonymity for the purpose of concealing the source of the illicit money. The forms of this activity include:

a. Transfer of funds from one bank to other bank and or inter region/country.

b. Use of cash deposits as collateral to support legitimate transactions.

c. Moving cross-border cash through a network of legitimate business activities or through a shell company.

3. Integration from illegal assets or money that is the effort to use property derived from criminal acts that have successfully entered into the financial system through placement or transfer so as to become a wealth of halal (clean money), for business activities which is lawful or to refinance criminal activities. Some forms of this Integration activity are:

a. Using assets that have seemed legitimate, whether to be enjoyed directly, invested in various forms of material and financial wealth.

b. Used to finance legitimate business activities, orc. Refinance criminal activities.

More detailed determination of narcotics crime as predicate crime on money laundering can be seen in Article 1 number 1 of Law Number 25 of 2003 concerning Money Laundering Crime that money laundering is defined as the act of placement, transfer, pay, spending, granting, donate, deposit , bringing abroad, exchange, or other acts of assets that are known or reasonably suspected to be the result of a criminal act with the intent to conceal or disguise the origin of assets so that they appear to be legitimate assets. 
Money laundering have special characteristics that distinguish against other criminal acts that money laundering crimes are follow up crimes, while the crime results of processed for money laundering are referred to as predicate offence. The purpose of the perpetrators to process money laundering from the results of narcotics crime is to conceal or disguise the results of the predicate offence so as not to be tracked for further use, the purpose is not to hide it but to change the origins of the narcotics crime results for the next purpose and to eliminate the direct relations with the original crime. It is thus clear that various crimes involving financial institutions especially narcotics crime will almost certainly be carried out money laundering or at least as soon as possible money laundering is done to hide the proceeds of narcotics crimes in order to avoid investigation and investigation and prosecution in criminal justice system.

It is shown that narcotics crime as an original crime can be seen from the actions of the perpetrators by hiding or disguise the origin of the assets obtained from the results of the narcotics crime so that it looks as if the assets resulting from the narcotics crime are the result of legal activities. The crime of money laundering with criminal offenses as long as the crime of narcotics abuse can be seen in Article 2 paragraph (1) of the Law of the Republic of Indonesia Number 8 of 2010 concerning Prevention and Eradication of Money Laundering Criminal Acts, that the proceeds of criminal acts are assets obtained from acts a criminal offense committed in the territory of the Republic of Indonesia or outside the territory of the Unitary State of the Republic of Indonesia and the crime is also a crime according to Indonesian law. The considerable wealth gained from narcotics abuse crimes, usually the perpetrators are not directly used by the perpetrators because of fear or are indicated as money laundering activities.

\subsection{Suspicious Financial Transactions in Narcotics Trading Results Meets the Element of Money Laundering}

Elucidation of Article 23 Paragraph (1) Letter a of the Law of the Republic of Indonesia Number 8 of 2010 concerning Prevention and Eradication of Money Laundering Criminal Acts is explained that Suspicious Financial Transactions are initiated from transactions including: ${ }^{14}$

a. Do not have a clear economic and business objectives.

b. Using relatively large amounts of cash and/or repeating out of the ordinary; or

c. Customer transaction activity outside of the ordinary and reasonable.

Understanding this will greatly assist the Investigator in conducting an investigation of the person or party who will be related to a transaction, understand it will also be able to reveal how the act or modus operandi

\footnotetext{
14 Article 23 paragraphs (1) point a Law of the Republic of Indonesia Number 8 of 2010 concerning Prevention and Eradication of Money Laundering Crimes (Lembaran Negara Republik Indonesia Tahun 2010 Nomor 122, Tambahan Lembaran Negara Nomor 5164)
} 
performed by certain parties in order to conceal or disguise the origin of their assets. Suspicious Financial Transactions based on the provisions of Article 1 paragraph (5) of the Law of the Republic of Indonesia Number 8 of 2010 concerning Prevention and Eradication of Money Laundering Acts including: 15

a. Financial Transactions that deviate from the profile, characteristics, or habits of the transaction patterns of the relevant Service Users.

b. Financial Transactions by an appropriate service user that is alleged to be done with the intention to avoid reporting the relevant transactions which must be carried out by the Reporting Party in accordance with the provisions of this Law.

c. Financial Transactions conducted or canceled by using Assets that are suspected to originate from proceeds of crime; or

d. Financial Transactions requested by PPATK to be reported by the Reporting Party because it involves Assets that are suspected to originate from the results of a criminal offense.

The National Narcotics Agency, in addition to revealing narcotics crimes, also discloses the crime of money laundering. In 2014 the national narcotics agency uncovered 11 criminal money laundering cases by securing 12 suspects who are Indonesian citizens over the age of 30 . Asset value after being converted into rupiah value is Rp. 77,584,753,378, - confiscated assets include cars, motorcycles, land, jewelry, houses and apartments. In addition there are still assets worth Rp.32,276,000,000 which are still being processed. ${ }^{16}$

Throughout 2015 the National Narcotics Agency has revealed as many as 102 cases of narcotics and money laundering crimes which are syndicates of national and international networks, of which as many as 82 cases have been P21.

The revealed case involved 202 suspects consisting of 174 Indonesian citizens and 28 foreigners. Based on all narcotics cases that have been revealed, the National Narcotics Agency has confiscated 1,780,272,364 grams of crystal methamphetamine; 1,200 milliliters of liquid methamphetamine; 1,100,141.57 grams of cannabis; 26 cannabis seeds; 95,86 canna chocolate; 303.2 grams of happy cookies; 14.94 grams of hashish; 606,132 ecstasy pills; and 32,253 milliliters of precursor fluid and 14.8 grams. Whereas in the case of money laundering the total assets that were confiscated by the National Narcotics Agency amounted to Rp 85,109,308,337. ${ }^{17}$

\footnotetext{
${ }^{15}$ Article 1 paragraphs (5) Law of the Republic of Indonesia Number 8 of 2010 concerning Prevention and Eradication of Money Laundering Crimes (Lembaran Negara Republik Indonesia Tahun 2010 Nomor 122, Tambahan Lembaran Negara Nomor 5164)

16 Appendix BNN End-Year Realease Press, Jakarta December 2015

17 Appendix BNN End-Year Realease Press, Jakarta December 2015
} 
Based on data from the results of the National Narcotics Agency research in collaboration with the University of Indonesia Health Research Center in 2014 on the National Survey of Narcotics Abuse Development in Indonesia it is known that the prevalence rate of narcotics abusers in Indonesia has reached $2.18 \%$ or around 3.8 million to 4,1 million people who have used narcotics in 2014 in the $10-59$ years age group. ${ }^{18}$

Suspicious financial transactions can be seen from the customer description profiles which include identity, occupation, business activities, and source of income and amount of income, characteristic as a special feature of customer transactions, which can differentiate customers or customer groups from one another. ${ }^{19}$ To identify the characteristics of the customer as the distinguishing factor is the business of the customer concerned, the customs pattern of transactions conducted by the customer. The report of suspicious financial transaction is a report, which are the obligations of Financial Service Providers, Goods and/or other Service Providers, which must be reported to PPATK. Submission of Suspicious Financial Transaction Reports, Financial Service Providers must first understand the criteria of suspicious financial transactions as referred to in Article 1 Number 5 of the Law of the Republic of Indonesia Number 8 of 2010 concerning Prevention and Eradication of Money Laundering Criminal Acts which begins with the identification of financial transactions that are not unusual (unusual transaction) by the monitoring system contained in the Financial Services Provider.

\section{Conclusion}

The narcotics trade utilizes financial institutions to carry out acts of concealment and disguise the assets resulting from narcotics crime. The crime of money laundering will not occur if it is not preceded by an original crime in this research which is the original criminal act is narcotics because the object of money laundering criminal is a wealth resulting from criminal acts Origin. The crime of money laundering with the criminal crime of origin does not have one bad intention (mens rea) the same, because the intention to commit a criminal offense as manifested in the act is different from the will to commit a criminal act of money laundering in Articles 3, 4 and 5 of Law No. 8 of 2010.

The crime of money laundering is not a single crime but a double crime. The crime of money laundering is a crime that is a follow-up crime or a further crime on the results of the main crime (core crime). Money laundering can occur at approximately the same time, and in the wake of narcotics. In the case of repeated criminal drug trafficking, criminal trafficking of narcotics and criminal money laundering can occur simultaneously. PPATK as a core institution should have pro justitia authority, including investigation and

\footnotetext{
18 Journal of Data on the Prevention and Eradication of Drug Abuse and Circulation in 2014 (P4GN) 2015 edition

${ }^{19}$ Regulation of the Head of PPATK NUMBER PER-09 / 1.02.2 / PPATK / 09/12 Regarding Procedures for Submitting Suspicious Financial Transaction Reports and Cash Financial Transaction Reports for Providers of Financial Services.
} 
analysis of reports. But, the Law of the Republic of Indonesia Number 8 of 2010 concerning the Prevention and Eradication of Money Laundering Acts does not explicitly and clearly give the task and authority of pro justisia only as an administrative institution. The mode of money laundering does not always proceed in stages, but rather by combining stages and following time to time and time again through numerous stages of money laundering, resulting in a complicated money laundering process involving many parties and services.

Object of that crime is money and the result of that crime is called dirty money.Whereas the change of the proceeds of crime into the form of legal results is known as net money, several substantial elements of money laundering are fulfilled with narcotics crime related to the process of money laundering because in narcotics, especially in conducting narcotics trafficking is part of organized crime includes the activity of placing some of the proceeds of crime into the financial system through Financial Service Providers, overlaying the money through various financial transactions to obscure its origin and reunite it in the form of investment in legitimate businesses within a certain period of time.

Money laundering do not stand alone as conventional crimes, but criminally related to other crimes. So it's safe to say that a felony is conditio sine qua non against domestic crime as cited in article 2 of the holy scriptures (1) of Law No. 8 of 2010. Therefore in the implementation of prosecution in terms of original intent, the original crime is still based on the aspect of the act and its maker (daad dader strafrecht), whereas the object of a money laundering is assets suspected to originate or be obtained from an original crime. The difference between the two objects of the criminal act has an impact on normative verification, that is proof of the original crime (against acts and mistakes of the maker), while proof of assets in money laundering is on the acquisition of assets suspected of originating from criminal acts.

\section{References}

4th paragraph Preamble of the 1945 Constitution of the Republic of Indonesia Republic of Indonesia. Explanation of Law Number 8 of 1974 concerning Personnel Principles. Supplement to the State Gazette of the Republic of Indonesia Number 3041.

Republic of Indonesia. Government Regulation Number 53 Year 2010 Concerning Discipline of Civil Servants. Republic of Indonesia State Gazette Number 74 of 2010 and Supplement to Republic of Indonesia State Gazette Number 5135.

Republic of Indonesia. Government Regulation Number 24 of 2011 concerning Personnel Advisory Board, State Gazette of the Republic of Indonesia of 2011 Number 45 and Supplement to State Gazette of the Republic of Indonesia Number 5210.

Republic of Indonesia Law Number 5 Year 2014 Concerning State Civil Apparatus Disciplined Civil Servants, State Gazette of the Republic of Indonesia Year 2014 Number 6 and Supplement to the Republic of Indonesia State Gazette Number 5494. 
A.E. Manihuruk. Development of Civil Servants in Development. Prisma Number 4. August 1974. Year III.

Circular of the Supreme Court of the Republic of Indonesia Number 4 of 2016 concerning the Imposition of the Formulation of the Results of the Plenary Meeting of the 2016 Supreme Court Room as a Guide to Implementing Duties for the Court.

C.S.T Kansil. Introduction to Indonesian Law and Legal Studies. Publisher: PN Balai Pustaka.

Jonaedi Efendi, Dr. Ismu Gunadi Widodo, and Fifit Fitri Lutfianingsih, Dictionary of Popular Legal Terms. Publisher: Prenadamedia Group. 2016

H. Nainggolan. Development of Civil Servants. 4th printing. BAKN. 1983.

Pandu Wibowo M.E. New Bureaucracy Designer Welcomes Millennial ASN Wave in Bureaucracy. Publisher: Phoenix Publisher. 2019.

Sovia Hasanah, Flow of State Administration Dispute Settlement. 2016. Quoted from: www.hukumonline.com.

Sondang P. Siagian. Administrative Philosophy. Seventh printing. PT. Holy mountain. Jakarta: 1974. 